\title{
ПРОБЛЕМЫ ЗАКОНОДАТЕЛЬНОГО ЗАКРЕПЛЕНИЯ КАТЕГОРИИ «ПРЕСТУПЛЕНИЯ ТЕРРОРИСТИЧЕСКОГО ХАРАКТЕРА»
}

\begin{abstract}
Аннотация: На основе анализа нормативных правовых актов Российской Федерации автором выявлен неоднозначный подход к закреплению понятия и перечня преступлений террористического характера. Количество преступлений данной категории колеблется от 8 до 18. При этом в категорию «преступления террористического характера» могут быть включены преступления экстремистской направленности и иные категории преступлений, что представляет возможность «двойного учета» преступных деяний. Указанная позиция законодательной ветви власти негативно отражается на распознавании террористических угроз и эффективной деятельности правоприменителей. Методологическую основу статьи составили современные достижения теории познания. В процессе исследования применялись общефилософские методы (диалектика, системный метод, анализ, синтез, аналогия, дедукиия, наблюдение, моделирование), традиционно правовые методы (формально-логический), а также методы, используемые в конкретно-сочиологических исследованиях (статистические, экспертные оценки и др.). При квалификации деяния как преступления террористического характера в первую очередь необходимо учитывать наличие террористической иели. Обосновывается необходимость закрепления понятия «преступления террористического характера» и исчерпывающего перечня данных преступлений на законодательном уровне. Реализация данного положения позволяет формировать объективную статистическую отчетность, на основе которой возможна разработка эффективных мер противодействия терроризму на территории РФ. Ключевые слова: терроризм, противодействие терроризму, преступление, преступность, экстремизм, уголовное законодательство, преступления террористического характера, статистика, террористическая цель, перечень преступлений.
\end{abstract}

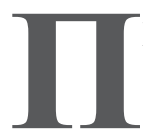
равовая основа противодействия терроризму в Российской Федерации является довольно развитой, благодаря чему в настоящее время успешно осуществляются необходимые меры предупреждения, пресечения, раскрытия, расследования преступлений террористического характера и наказания виновных лиц. Многие из имеющихся положений выработаны на основе опыта, с учетом имевшихся пробелов и ошибок. Однако в правовом обеспечении противодействия терроризму в настоящее время существует ряд проблем, разрешение которых во многом будет способствовать дальнейшему повышению эффективности антитеррористической деятельности.

В научном обороте используются понятия «террористические преступления» ${ }^{1}$, «преступления тер-

\footnotetext{
1 Щеблыкина И.В. Террористические преступления: проблемный характер оценки террористических угроз в Российской Федерации // Научный портал МВД России. - 2013. №1. - С. $72-76$.
}

рористического характера»², «преступления террористической направленности», «террористические проявления» ${ }^{4}$. С. У. Дикаев и И. Р. Диваева, например, в своем исследовании выделяют преступления террористического характера (статьи 205.1, 206, 207, 277, 208, 360 УК РФ) и преступления террористической направленности (статьи 209, 210, 211 УК РФ)5.

\footnotetext{
2 Артюшина О.В. Криминологическая характеристика и предупреждение преступлений террористического характера: научнопрактическое пособие. - Казань: КЮИ МВД России, 2009. - 105 с.

3 Ильин Е.П. Система противодействия идеологии терроризма в Российской Федерации: становление и перспективы развития // Вестник Национального антитеррористического комитета. - 2010. - № 2. - C. 22.

4 Выступление заместителя директора ФСБ России, руководителя аппарата Национального антитеррористического комитета генерал-полковника В.Г. Кулишова // Вестник Национального антитеррористического комитета. - 2010. - № 2. - С. 12.

5 Дикаев С.У., Диваева И.Р. Уголовная ответственность за преступления террористического характера»: учебное пособие. - М.: ЦОКР МВД России, 2005. - 72 с.
} 


\section{Национальная безопасность - № 4(33) • 2014}

В нормативной правовой сфере термин «преступление террористического характера» в настоящее время употребляется в п. «б» статьи 11 Концепции противодействия терроризму от 5 октября 2009 г., однако его определение и перечень преступлений террористического характера в акте не раскрыты. Кроме того, в действующем российском законодательстве отсутствует как само понятие «преступление террористического характера», так и закрытый перечень преступлений данной категории, вследствие чего, по мнению исследователей, «общественность и правоохранительные органы не способны должным образом адекватно реагировать на различного рода преступные проявления, оценивая их в качестве террористических» ${ }^{6}$.

Федеральный закон РФ «О противодействии терроризму» от 6 марта 2006 г. №35-Ф3, в отличие от утратившего силу 1 января 2007 г. Федерального закона РФ «О борьбе с терроризмом», не содержит понятия «преступления террористического характера». В части 2 статьи 24 действующего Закона лишь указывается, что «организация признается террористической и подлежит ликвидации (ее деятельность - запрещению)...в случае, если от имени или в интересах организации осуществляются организация, подготовка и совершение преступлений, предусмотренных статьями 205 - 206, 208, 211, 220, 221, 277 - 280, 282.1, 282.2 и 360 Уголовного кодекса Российской Федерации». Таким образом, при определении перечня преступлений террористического характера законодатель включил в него статьи о преступлениях экстремистской направленности: 280, 282.1, 282.2 УК РФ, которые, по мнению ряда исследователей, к терроризму относятся лишь косвенно ${ }^{7}$ или не относятся вовсе ${ }^{8}$.

\footnotetext{
6 Шмыгун А.Н. О содержании понятия преступлений террористического характера // Международное сообщество и глобализация угроз безопасности: сборник научных докладов. В 2 ч. Ч. 1. Исторические, теоретические и правовые аспекты противодействия угрозам национальной безопасности / отв. ред. В. В. Грохотова, Б. Н. Ковалев, Е. А. Макарова. - Великий Новгород: Новгородский Технопарк, 2008. - С. 296.

7 Петрушенков А.Н. Несовершенство уголовного законодательства в сфере противодействия преступлениям террористической направленности // Вестник Национального антитеррористического комитета. - 2010. - №2. - С. 85.

8 Шмыгун А.Н. О содержании понятия преступлений террористического характера // Международное сообщество и глобализация угроз безопасности: сборник научных докладов. В 2 ч. Ч. 1. Исторические, теоретические и правовые аспекты противодействия угрозам национальной безопасности / отв. ред.
}

Как представляется, позиция законодателя связана, в первую очередь, с реализацией положений статьи 1 Федерального закона «О противодействии экстремистской деятельности» от 25 июля 2002 г. №114-Ф3, в соответствии с которой террористическая деятельность является частью экстремистской. Однако подобный подход на практике может быть оценен как возможность двойного учета одного преступления и в качестве террористического, и в качестве экстремистского, что, в целях объективной статистики и разработки на ее основе соответствующих мер противодействия, недопустимо.

В Уголовном кодексе Российской Федерации содержится шесть составов преступлений, наименования или диспозиции которых указывают на непосредственную принадлежность к терроризму: статьи 205 - 205.5, часть из которых содержит в себе ссылку на перечень преступлений террористического характера.

В диспозиции части первой ст. 205.1 УК РФ «Содействие террористической деятельности», введенной в действие Федеральным законом от 27 июля 2006 г. №153-Ф3, криминализуется содействие террористической деятельности, то есть совершение преступлений, предусмотренных статьями 205, 206, 208, $211,277,278,279$ и 360 УК РФ. В примечании 1 к указанной статье законодатель при определении финансирования терроризма террористический перечень дополнил статьями 205.1, 205.2, 205.3, 205.4, 205.5, 220,221 . Аналогичный перечень закреплен в статье 3 Федерального закона РФ «О противодействии легализации (отмыванию) доходов, полученных преступным путем, и финансированию терроризма» от 7 августа 2001 г. №115-Ф3. В п. 16 Постановления Пленума Верховного Суда РФ №1 «О некоторых вопросах судебной практики по уголовным делам о преступлениях террористической направленности» от 9 февраля 2012 г. разъясняется, что «финансированием терроризма следует признавать, наряду с оказанием финансовых услуг, предоставление или сбор не только денежных средств (в наличной или безналичной форме), но и материальных средств (например, предметов обмундирования, экипировки, средств связи) с осознанием того, что они предназна-

В. В. Грохотова, Б. Н. Ковалев, Е. А. Макарова. - Великий Новгород: Новгородский Технопарк, 2008. -С. 295-296; Артюшина О.В. Криминологическая характеристика и предупреждение преступлений террористического характера: научно-практическое пособие. - Казань: КЮИ МВД России, 2009. - С. 9. 
чены для финансирования организации, подготовки или совершения хотя бы одного из преступлений, предусмотренных статьями 205, 205.1, 205.2, 206, 208, 211, 277, 278, 279 и 360 УК РФ».

Следует отметить применение судом понятия «преступления террористической направленности», а не «преступления террористического характера».

Вновь введенная статья 205.3 УК РФ «Прохождение обучения в целях осуществления террористической деятельности» устанавливает ответственность за прохождение обучения в целях осуществления террористической деятельности либо совершения одного из преступлений, предусмотренных статьями 205.1, 206, 208, 211, 277, 278, 279 и 360 УК РФ.

Статья 205.4 УК РФ «Организация террористического сообщества и участие в нем» криминализует создание террористического сообщества «в целях осуществления террористической деятельности либо для подготовки или совершения одного либо нескольких преступлений, предусмотренных статьями 205.1, 205.2, 206, 208, 211, 220, 221, 277, 278, 279 и 360».

Таким образом, анализ нормативных правовых актов Российской Федерации показывает, что количество преступлений террористического характера колеблется от 8 до 18. Налицо неоднозначный подход законодателя к перечню преступлений данной категории, что, по мнению М. В. Омигова, вводит правоприменителей в заблуждение 9 . Необходимо законодательное закрепление перечня преступлений террористического характера, так как его отсутствие «негативно отражается на диагностике террористических угроз» ${ }^{10}$.

Непосредственные правоприменители законодательства Российской Федерации в сфере противодействия терроризму, при отнесении преступлений к категории «преступление террористического характера» ${ }^{11}$ руководствуются межведомствен-

\footnotetext{
9 Омигов М.В. Проблемы квалификации преступлений в сфере экстремизма и терроризма // Вестник Национального антитеррористического комитета, 2011. - №3. - С. 100-107.

10 Щеблыкина И.В. Террористические преступления: проблемный характер оценки террористических угроз в Российской Федерации // Научный портал МВД России. - 2013. - №1. - С. 74.

11 Органы внутренних дел (полиция) на практике при квалификации деяний как преступление террористического характера руководствуется в первую очередь данным Указанием. См.: Киреев М.П., Трофимов Д.С., Грузовский А.Н. Перечень преступлений террористического характера по законодательству России (проблемы определения) // Информатизация и
}

ным нормативным правовым актом: Указанием Генеральной прокуратуры №387-11 и МВД России №2 от 11 сентября 2013 г. «О введении в действие перечня статей Уголовного кодекса Российской Федерации, используемых при формировании статистической отчетности», изданным в целях обеспечения единого подхода и полноты отражения в формах федерального статистического наблюдения сведений о состоянии преступности в Российской Федерации. Указанием, так же, как и предшествующими аналогичными актами (268/85/2 от 16 декабря 2008 г., №399/11/1 от 28 декабря 2009 г., №450/85/3 от 28 декабря 2010 г., №52/11/2 от 15 февраля 2012 г.), закреплен Перечень №22 «Преступления террористического характера».

Согласно указанному Перечню с 1 января 2013 г. в Российской Федерации преступлениями террористического характера являются:

1. преступления, предусмотренные статьями 205 , 205.1, 205.2, 206, 208, 277, 281, 360 УК РФ;

2. преступления, предусмотренные статьями 207, 211 (учитываются в случае возбуждения уголовных дел до 10 марта 2006 г.), 220, 221 (учитываются в случае возбуждения уголовных дел до 29 октября 2010 г.) УК РФ;

3. преступления, предусмотренные статьями 278 , 279, 282.1, 282.2 УК РФ, учитываются в случае возбуждения уголовных дел до 10 марта 2006 г. и при наличии связи совершенных преступлений с террористической деятельностью, террористической организацией либо финансированием акта терроризма;

4. преступления, предусмотренные статьями 295, 317, 318 УК РФ, при наличии связи совершенных преступлений с террористической деятельностью.

В целях статистического учета наличие связи устанавливается путем соответствующей отметки в статистической карточке о совершенном преступлении.

Примечательно, что в предыдущем Перечне 2012 года статьи 295, 317, 318 УК РФ к преступлениям террористического характера не относились, вне зависимости от их связи с террористической деятельностью.

Как было указано, с 10 марта 2006 года, в связи с введением в действие закона «О противодействии терроризму», статья 207 УК РФ «Заведомо ложное сообщение об акте терроризма» исключена из Перечня преступлений террористического характера, что, на

информационная безопасность правоохранительных органов. М.: Академия управления МВД России, 2013. - С. 109-113. 


\section{Национальная безопасность - № 4(33) • 2014}

наш взгляд, представляется справедливым и обоснованным. Объектом посягательства заведомо ложного сообщения об акте терроризма является не общественная безопасность, а общественный порядок и нормальная деятельность учреждений. Совершается указанное преступление чаще всего из хулиганских побуждений и не преследует террористическую цель: дестабилизацию деятельности органов власти и международных организаций или воздействие на приятие ими решения. И, как указывают исследователи, в случае наличия террористической цели преступление следует квалифицировать как угрозу совершения акта терроризма ${ }^{12}$.

Следует учитывать, что в основе всех преступлений террористического характера лежит сложное многогранное социально - политическое явление - терроризм, поэтому, по нашему мнению, основанием при квалификации конкретного деяния как преступления данной категории необходимо руководствоваться, прежде всего, наличием террористической цели, указанной в статье 205 УК РФ, - дестабилизация деятельности органов власти либо международных организаций или воздействие на принятие ими решения. При этом, по мнению М. В. Андреева, в статье 205 УК РФ перечислены не все цели, для достижения которых может быть совершен террористический акт. Так, например, «провокация войны, изменение репутации страны в международном общественном мнении и многие другие цели могут иметь место» ${ }^{13}$.

Следует отметить, что в судебно - следственной практике оговаривается необходимость документального отражения перечня органов власти, на которые виновные лица желали оказать воздействие ${ }^{14}$, а исследователями акцентируется внимание на том, что решение должно быть выгодным террористам ${ }^{15}$.

Ранее положение об отнесении преступления к перечню террористических в связи с наличием террористической цели содержалось в статье 3

12 Мусаелян М.Ф. Цель как признак террористического акта // Законность.-2010. - №6. - С. 40.

13 Андреев М.В. Проблемы противодействия терроризму в международно - правовой доктрине // Вестник Казанского юридического института МВД России. - 2013. - №2. - С. 19.

14 Постановление о возвращении уголовного дела прокурору // Дело №2-27/2006 (Архив Верховного суда Республики Татарстан).

15 Мусаелян М.Ф. Цель как признак террористического акта // Законность.- 2010. - №6. - С. 39. утратившего силу закона «О борьбе с терроризмом». В настоящее время подобное положение на законодательном уровне не закреплено, и лишь некоторые статьи Уголовного кодекса России содержат в себе указание на специальную цель.

Так, статьи 205.3 и 205.4 УК РФ оговаривают цель прохождения обучения и создания террористического сообщества - осуществление террористической деятельности либо совершение конкретных преступлений террористического характера.

Федеральным законом от 5 мая 2014 г. №130 - Ф3 введена в действие часть 4 статьи 211 УК РФ «Угон воздушного или водного транспорта либо железнодорожного подвижного состава» следующего содержания: «Деяния, предусмотренные частями первой, второй или третьей настоящей статьи, сопряженные с совершением террористического акта либо иным осуществлением террористической деятельности, наказываются лишением свободы на срок от пятнадцати до двадцати лет с ограничением свободы на срок от одного года до двух лет или пожизненным лишением свободы». Часть 4, в сравнении с иными частями статьи, предусматривает наиболее строгую ответственность.

Таким образом, на основе комплементарного анализа существующих пробелов формулирования категории «преступление террористического характера» можно сделать вывод о необходимости законодательного закрепления понятия и исчерпывающего перечня преступлений данной категории. При формировании указанной категории в первую очередь следует руководствоваться наличием в уголовной норме специальной террористической цели. Законодательное закрепление категории «преступления террористического характера» в свою очередь позволит исключить практику «двойного» учета деяний в качестве преступлений террористического характера и преступлений экстремистской направленности и формировать объективную статистическую отчетность. 


\section{Библиография:}

1. Щеблыкина И. В. Террористические преступления: проблемный характер оценки террористических угроз в Российской Федерации // Научный портал МВД России. - 2013. - № 1.

2. Артюшина О. В. Криминологическая характеристика и предупреждение преступлений террористического характера: научно - практическое пособие. - Казань: КЮИ МВД России, 2009.

3. Ильин Е. П. Система противодействия идеологии терроризма в Российской Федерации: становление и перспективы развития // Вестник Национального антитеррористического комитета. - 2010. - № 2.

4. Выступление заместителя директора ФСБ России, руководителя аппарата Национального антитеррористического комитета генерал-полковника В. Г. Кулишова // Вестник Национального антитеррористического комитета. - 2010. - № 2.

5. Дикаев С. У., Диваева И. Р. Уголовная ответственность за преступления террористического характера»: учебное пособие. - М.: ЦОКР МВД России, 2005.

6. Шмыгун А. Н. О содержании понятия преступлений террористического характера // Международное сообщество и глобализация угроз безопасности: сборник научных докладов. В 2 ч. Ч. 1. Исторические, теоретические и правовые аспекты противодействия угрозам национальной безопасности / отв. ред. В. В. Грохотова, Б. Н. Ковалев, Е. А. Макарова. - Великий Новгород: Новгородский Технопарк, 2008.

7. Петрушенков А. Н. Несовершенство уголовного законодательства в сфере противодействия преступлениям террористической направленности // Вестник Национального антитеррористического комитета. 2010. - №2.

8. Омигов М. В. Проблемы квалификации преступлений в сфере экстремизма и терроризма // Вестник Национального антитеррористического комитета, 2011. - №3.

9. Органы внутренних дел (полиция) на практике при квалификации деяний как преступление террористического характера руководствуется в первую очередь данным Указанием. См.: Киреев М. П., Трофимов Д. С., Грузовский А. Н. Перечень преступлений террористического характера по законодательству России (проблемы определения) // Информатизация и информационная безопасность правоохранительных органов. - М.: Академия управления МВД России, 2013.

10. Мусаелян М. Ф. Цель как признак террористического акта // Законность. - 2010. - №6.

11. Андреев М. В. Проблемы противодействия терроризму в международно - правовой доктрине // Вестник Казанского юридического института МВД России. - 2013. - №2.

12. Постановление о возвращении уголовного дела прокурору // Дело №2-27/2006 (Архив Верховного суда Республики Татарстан).

13. А. Э. Жалинский Криминологическая характеристика терроризма в России // Национальная безопасность / nota bene. - 2012. - 2. - C. 22-29.

14. Корнилов Т.А. Правовое регулирование противодействия экстремизму // Административное и муниципальное право. - 2011. - 8. - С. 51-55.

15. Макарова Т.В. Основания классификации жертв терроризма // NB: Вопросы права и политики. - 2014. 4. - C. 29-58. DOI: 10.7256/2305-9699.2014.4.9328. URL: http://www.e-notabene.ru/lr/article 9328.html

16. В. М. Быков Постановление Пленума Верховного Суда Российской Федерации о судебной практике по уголовным делам: о преступлениях экстремистской направленности: научный комментарий // Право и политика. - 2011. - 9. - С. 1477-1484.

\section{References:}

1. Shcheblykina I. V. Terroristicheskie prestupleniya: problemnyi kharakter otsenki terroristicheskikh ugroz $\mathrm{v}$ Rossiiskoi Federatsii // Nauchnyi portal MVD Rossii. - 2013. - №1.

2. Artyushina O. V. Kriminologicheskaya kharakteristika i preduprezhdenie prestuplenii terroristicheskogo kharaktera: nauchno - prakticheskoe posobie. - Kazan’: KYuI MVD Rossii, 2009.

3. Il'in E. P. Sistema protivodeistviya ideologii terrorizma v Rossiiskoi Federatsii: stanovlenie i perspektivy razvitiya // Vestnik Natsional'nogo antiterroristicheskogo komiteta. - 2010. - № 2. 


\section{Национальная безопасность - № 4(33) • 2014}

4. Vystuplenie zamestitelya direktora FSB Rossii, rukovoditelya apparata Natsional'nogo antiterroristicheskogo komiteta general-polkovnika V. G. Kulishova // Vestnik Natsional'nogo antiterroristicheskogo komiteta. 2010. - № 2.

5. Dikaev S. U., Divaeva I. R. Ugolovnaya otvetstvennost' za prestupleniya terroristicheskogo kharaktera»: uchebnoe posobie. - M.: TsOKR MVD Rossii, 2005.

6. Shmygun A. N. O soderzhanii ponyatiya prestuplenii terroristicheskogo kharaktera // Mezhdunarodnoe soobshchestvo i globalizatsiya ugroz bezopasnosti: sbornik nauchnykh dokladov. V $2 \mathrm{ch}$. Ch. 1. Istoricheskie, teoreticheskie i pravovye aspekty protivodeistviya ugrozam natsional'noi bezopasnosti / otv. red. V. V. Grokhotova, B. N. Kovalev, E. A. Makarova. - Velikii Novgorod: Novgorodskii Tekhnopark, 2008.

7. Petrushenkov A. N. Nesovershenstvo ugolovnogo zakonodatel'stva $\mathrm{v}$ sfere protivodeistviya prestupleniyam terroristicheskoi napravlennosti // Vestnik Natsional'nogo antiterroristicheskogo komiteta. - 2010. - №2.

8. Omigov M. V. Problemy kvalifikatsii prestuplenii v sfere ekstremizma i terrorizma // Vestnik Natsional'nogo antiterroristicheskogo komiteta, 2011. - №3.

9. Organy vnutrennikh del (politsiya) na praktike pri kvalifikatsii deyanii kak prestuplenie terroristicheskogo kharaktera rukovodstvuetsya v pervuyu ochered' dannym Ukazaniem. Sm.: Kireev M. P., Trofimov D. S., Gruzovskii A. N. Perechen' prestuplenii terroristicheskogo kharaktera po zakonodatel'stvu Rossii (problemy opredeleniya) // Informatizatsiya i informatsionnaya bezopasnost' pravookhranitel'nykh organov. - M.: Akademiya upravleniya MVD Rossii, 2013.

10. Musaelyan M. F. Tsel’ kak priznak terroristicheskogo akta // Zakonnost'. - 2010. - №6.

11. Andreev M. V. Problemy protivodeistviya terrorizmu v mezhdunarodno - pravovoi doktrine // Vestnik Kazanskogo yuridicheskogo instituta MVD Rossii. - 2013. - №2.

12. Postanovlenie o vozvrashchenii ugolovnogo dela prokuroru // Delo №2-27/2006 (Arkhiv Verkhovnogo suda Respubliki Tatarstan).

13. A. E. Zhalinskii Kriminologicheskaya kharakteristika terrorizma v Rossii // Natsional'naya bezopasnost' / nota bene. $-2012 .-2 .-$ S. 22-29.

14. Kornilov T.A. Pravovoe regulirovanie protivodeistviya ekstremizmu // Administrativnoe i munitsipal'noe pravo. 2011. - 8. - S. 51-55.

15. Makarova T.V. Osnovaniya klassifikatsii zhertv terrorizma // NB: Voprosy prava i politiki. - 2014. - 4. - S. 29-58. DOI: 10.7256/2305-9699.2014.4.9328. URL: http://www.e-notabene.ru/lr/article_9328.html

16. V. M. Bykov Postanovlenie Plenuma Verkhovnogo Suda Rossiiskoi Federatsii o sudebnoi praktike po ugolovnym delam: o prestupleniyakh ekstremistskoi napravlennosti: nauchnyi kommentarii // Pravo i politika. - 2011. - 9. S. 1477-1484. 